\title{
Heaviest Precambrian shale U isotopes to date: Oxygenation in the 2.0 Ga Zaonega Formation, Russia
}

K. MÄND*1, S. V. LALONDE ${ }^{2}$, L. J. ROBBINS ${ }^{3}$, M.

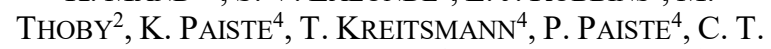
REINHARD $^{5}$, A. E. ROMASHKIN ${ }^{6}$, N. J. PlaNAVSKY ${ }^{3}$, K. KIRSIMÄE $^{4}$, A. LEPLAND ${ }^{7}$ AND K. O. KONHAUSER ${ }^{1}$

${ }^{1}$ University of Alberta, Edmonton, AB T6G 2E3, Canada (*correspondence: kaarel.mand@ualberta.ca) ${ }^{2}$ CNRS-UMR6538 LGO, UBO, 29280 Plouzané, France

${ }^{3}$ Yale University, New Haven, CT 06511, USA

${ }^{4}$ University of Tartu, 50411 Tartu, Estonia

${ }^{5}$ Georgia Tech, Atlanta, GA 30332, USA

${ }^{6}$ Karelian Science Centre, 185610 Petrozavodsk, Russia

${ }^{7}$ Geological Survey of Norway, 7491 Trondheim, Norway

The initial rise of oxygen in the Paleoproterozoic was followed by a massive positive $\mathrm{C}$ isotope excursion known as the Lomagundi Event (LE), 2.3-2.05 Ga. A widely-accepted explanation for the LE invokes an elevated organic $\mathrm{C}$ to carbonate $\mathrm{C}$ burial ratio, which would have additionally resulted in the release of vast amounts of free $\mathrm{O}_{2}$ [1]. Yet, this implies unlikely levels of bioproduction and very few organic-rich deposits are known from the time.

To test this mechanism, we study $\mathrm{U}, \mathrm{Mo}$, and $\mathrm{Cr}$ isotopes in immediately post-LE $(\sim 2.0 \mathrm{Ga})$ shales of the Zaonega Formation (ZF), Russia [2]. If organic carbon burial was responsible for the $\mathrm{LE}, \mathrm{O}_{2}$ production was likely to have lessened by the time of ZF deposition. Yet, we find $\delta^{238} \mathrm{U}$ values up to $0.79 \pm 0.09 \%$ in the $\mathrm{ZF}$, the highest reported to date from Precambrian shales. This is significant because even with maximum fractionation from seawater to sediments, such values require a marine $U$ pool at nearly the modern $\delta^{238} \mathrm{U}$ composition of $\sim-0.4 \%$. This suggests a limited extent of ocean anoxia, as anoxic sediments preferentially scavenge ${ }^{238} \mathrm{U}$ from seawater, leaving the residual pool ${ }^{238} \mathrm{U}$-depleted.

These data, combined with fractionated $\mathrm{Cr}$ isotopic ratios and high $\mathrm{Mo}, \mathrm{U}$, and $\mathrm{Cr}$ abundance, suggest highly oxidized global oceans at the time of ZF deposition. Since our data come from firmly post-LE strata, this contradicts the idea that $\mathrm{O}_{2}$ production decreased rapidly following the end of the LE, indicating against organic carbon burial as a driver of the LE carbon isotope excursion. Instead, alternative explanations are needed for these profound perturbations in the Paleoproterozoic $\mathrm{O}_{2}$ and $\mathrm{C}$ cycles.

[1] Karhu \& Holland (1996) Geology 14, 867-870. [2] Mänd et al. (accepted) Nat. Geosci. 